\title{
EVALUASI DIRI PERILAKU PROFESIONAL DI INSTITUSI SEKOLAH TINGGI ILMU KESEHATAN GUNA BANGSA YOGYAKARTA
}

\author{
Widuri ${ }^{1}$, Amitya Kumara ${ }^{2}$, Tridjoko Hadianto ${ }^{3}$ \\ ${ }^{1}$ Graduate student of Medical Education of Medical Faculty of Gadjah Mada University \\ ${ }^{2}$ Graduate lecturer of Medical Education of Medical Faculty of Gadjah Mada University \\ ${ }^{3}$ Graduate lecturer of Medical Education of Medical Faculty of Gadjah Mada University
}

\begin{abstract}
Background: Education world has a very important role in improving the quality of human resources, as it is the environment in which the process of the formation of professional behavior through a series of teaching and learning process. Professional behavior should be clearly seen as an aspect of personal identity and character developed over time. Based on this, the focus of professionalism began to shift from individual to the institution and stated that professionalism must be embedded in an educational institution with a complete integration of the culture of professionalism that involves the institution leader, staffs, lecturers, and students. The purpose of this study is to investigate the professional behavior of the institution of Sekolah Tinggi llmu Kesehatan Guna BangsaYogyakarta.

Methods: This study is a descriptive qualitative research. Subjects were the institutional leader, lecturers, staffs and students are determined by purposive sampling. Interview instruments include altruism, honor and integrity, caring and compassion, respect for others, responsibility and accountability, excellence and scholarship, and leadership. Participant at the data collection focused group discussion (FGD) is 10 persons and on interview data collection is 21 persons. Efforts to achieve the credibility of the informant are done by triangulation and discussions with colleagues. Research supervisor role as auditors, maintain dependency and certainty degree of this research.

Results: Participants considered that the lecturers, staffs, students and institutional leader have done with the guidance of a good, high integrity, good communication, mutual respect, responsibility and provide exemplary. However, some behavioral components still require improvement such as the level of lecturers' discipline, staffs' job and responsibility distribution, student discipline and responsibility, and supervisor leadership patterns.

Conclusion: As there are still some components of professional behavior that needs any improvement, requires institutions to increase self-understanding and awareness to professional behavior. Institutions need to consider any strategies to be taken to overcome any problems faced by the institution to achieve professional behavior.
\end{abstract}

Keywords: professional behavior, professionalism

\section{PENDAHULUAN}

Kualitas manusia yang dibutuhkan oleh bangsa Indonesia pada masa yang akan datang adalah yang mampu menghadapi persaingan yang semakin ketat dengan bangsa lain di dunia. Kualitas manusia Indonesia tersebut dapat dihasilkan melalui penyelenggaraan pendidikan yang bermutu.

Dunia pendidikan mempunyai peranan yang sangat penting dalam upaya meningkatkan kualitas sumber daya manusia, karena merupakan lingkungan tempat berlangsungnya proses pembentukan profesi melalui serangkaian proses belajar mengajar. Salah satu komponen utama dalam sistem pendidikan di perguruan tinggi adalah dosen.

Pendidikan profesional belum sejalan dengan tantangan, terutama karena terfragmentasi, ketinggalan jaman, dan kurikulum yang statis serta adanya masalah

sistemik yaitu adanya ketidakcocokan kompetensi, kurangnya kerja tim, stratifikasi gender, teknis fokus tanpa pemahaman kontekstual yang luas, ketidakseimbangan kuantitatif dan kualitatif tenaga kerja profesional, dan kepemimpinan yang lemah untuk meningkatkan sistem kinerja (Frenk et. al, 2010). ${ }^{1}$

Sosiologi cenderung menyoroti isu-isu kerja dan organisasinya yaitu dengan adanya kontrol kerja oleh individu yang sangat terampil dan khusus (misalnya profesional), kontrol oleh birokrasi (misalnya manajer) dan kontrol dari pasar bebas (misalnya konsumen). Hal tersebut memerlukan eksplorasi variabel struktural, seperti bentukbentuk organisasi yang berbeda, mekanisme pembayaran, atau inisiatif kebijakan, yang mungkin meningkatkan atau menghambat ekspresi profesionalisme ditingkat individu, organisasi atau social (Hafferty \& Castellani, 2009). ${ }^{2}$ 
Baru-baru ini, Royal College of Physicians of London's Working Party on Medical Professionalism telah mendefinisikan profesionalisme medis singkat sebagai seperangkat nilai-nilai, perilaku dan hubungan yang mendukung kepercayaan publik dengan berkomitmen untuk integrity, compassion, altruism, continuous improvement, excellence dan teamwork.

Meskipun demikian, penting untuk menekankan bahwa masih ada ketidakpastian tentang apa sebenarnya yang dimaksud profesionalisme dan meskipun pendidik bidang medis mendefinisikan profesionalisme sebagai karakteristik atau perilaku, sosiolog banyak mendukung teori-teori yang menggabungkan dimensi politik, ekonomi dan sosial ke dalam pemahaman tentang alam dan fungsi profesionalisme. Selain itu, profesionalisme harus dilihat dengan jelas sebagai aspek identitas pribadi dan karakter yang berkembang sepanjang waktu. Berdasarkan hal tersebut, fokus profesionalisme mulai bergeser dari individu ke lembaga dan dinyatakan bahwa profesionalisme harus ditanamkan dalam institusi pendidikan dengan integrasi lengkap dari budaya profesionalisme yang melibatkan staf, dosen, dan mahasiswa (Passi et. al, 2010). ${ }^{3}$

\section{Definisi Perilaku Profesional}

Perilaku profesional mengacu pada perilaku yang dapat diamati yang mencerminkan nilai-nilai dan standar profesional. Perilaku profesional dibuktikan dengan kata-kata, perilaku, penampilan dan hal tersebut sangat penting dalam membangun dasar kepercayaan dengan orang lain.

Karakteristik profesional menurut teori Green (2004) meliputi professionalism, thinking, planning and setting expectations, leading, dan relating to others. ${ }^{4}$

Menurut The Association of American Medical Colleges (AAMC) dan The National Board of Medical Examiners (NBME) (2002), perilaku profesional meliputi altruism, honor and integrity, caring and compassion, respect for others, responsibility and accountability, excellence and scholarship, dan leadership. ${ }^{5}$

Menurut Murray (1996), prinsip etika dalam mengajar dalam meningkatkan profesionalisme pengajar meliputiContent Competence,Pedagogical Competence, Dealing with Sensitive Topics, Student Development, Dual Relationships with Students, Confidentiality, Respect for Colleagues, Valid Assessment of Students, dan Respect for Institution. ${ }^{6}$

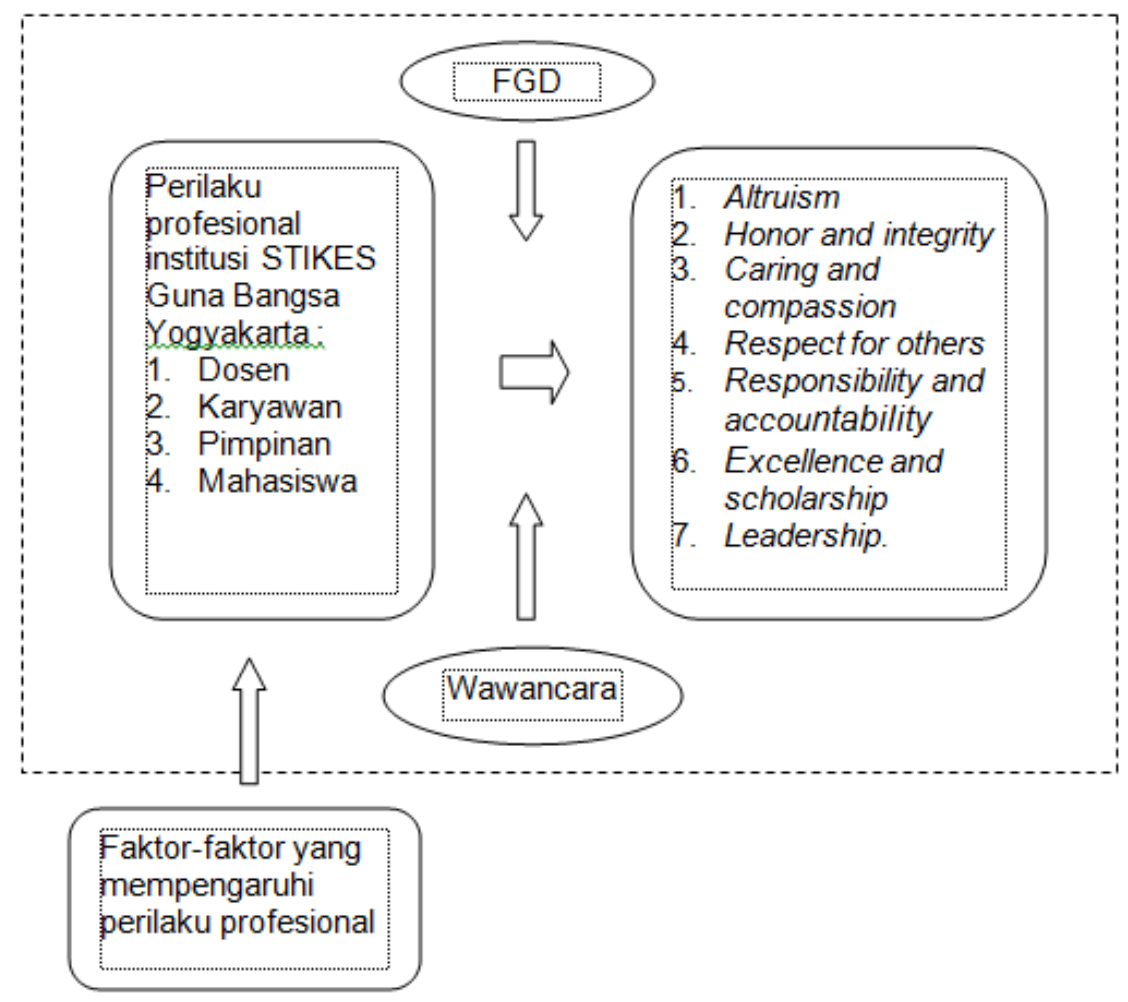




\section{METODE PENELITIAN}

Penelitian ini merupakan penelitian kualitatif deskriptif.Penelitian kualitatif adalah metode penelitian yang digunakan untuk meneliti pada kondisi obyek alamiah, dimana peneliti adalah sebagai instrumen kunci(Satoridan Komariah, 2010). ${ }^{7}$ Hasil penelitian kualitatif lebih menekankan makna daripada generalisasi.

Penelitian ini dilakukan di Sekolah Tinggi IImu Kesehatan Guna Bangsa Yogyakarta dengan populasi penelitian adalah seluruh pimpinan, dosen, karyawan dan mahasiswa. Jumlah pimpinan adalah tiga orang, dosen sebanyak 21 orang, karyawan sebanyak 41 orang, dan mahasiswa sebanyak 870 orang.

Sampel penelitian ditetapkan dengan caraaccidental sampling, merupakan teknik penentuan sampel berdasarkan faktor spontanitas (Riduwan, 2004). ${ }^{8}$ Pemilihan sampel berdasarkan pada kriteria inklusi, yaitu narasumber bertugas pada saat penelitian dilakukan dan bersifat netral. Sampel pada penelitian kualitatif dapat berkisar antara $n=1$ sampai $n=40$ atau lebih (McMillan dan Schumacher, 2001). ${ }^{9}$

Pada penelitian ini peneliti membuat pedoman Focused Group Discussion (FGD) dan wawancara untuk menggali data yang lebih mendalam. Panduan Focused Group Discussion (FGD) dan wawancara mengenai perilaku profesional institusi meliputi altruism, honor and integrity, caring and compassion, respect for others, responsibility and accountability, excellence and scholarship, dan leadership (AAMC and NBME, 2002). ${ }^{5}$ Konten pedoman wawancara telah dikonsultasikan kepada pembimbing. Untuk menghindari bias pada pengambilan data dibantu oleh seorang asisten dengan kualifikasi lulusan S1 Psikologi dan berpengalaman dalam penelitian.

Pengambilan data pertama pada FGD melibatkan 10 orang narasumber yang dikumpulkan dalam satu ruang pertemuan dan difasilitasi oleh fasilitator.Sebelum dilakukan FGD, peneliti telah melakukan persamaan persepsi dengan asisten peneliti selaku fasilitator.Pada forum diskusi, fasilitator mengeksplorasi opini dan pandanganpandangan narasumber tentang perilaku profesional institusi dan usulan perbaikannya. Selama proses diskusi dilengkapi dengan alat perekam, sehingga membantu dalam analisis data. Narasumber mendapatkan souvenir, makan siang dan jaminan kerahasiaan atas pernyataan yang telah disampaikan.
Pengambilan data kedua dengan wawancara semi struktur.Pada wawancara semi struktur, peneliti membuat garis besar pokok-pokok pembicaraan tetapi dalam pelaksanaannya interviewer mengajukan pertanyaan secara bebas.Wawancara dilakukan oleh seorang interviewer secara bergantian dalam suatu ruangan.Sebelum dilakukan wawancara, peneliti melakukan persamaan persepsi dengan asisten peneliti selaku interviewer.Narasumber pada tahap wawancara berjumlah 21 orang dan data yang diperoleh dinilai sudah jenuh serta dianggap sudah cukup mewakili populasi.

Cara analisis data dalam penelitian kualitatif adalah dengan melakukan koding.Dalam melakukan koding, peneliti sebelumnya mempersiapkan kelengkapan transkrip.Koding dilakukan dengan menggunakan bantuan program Atlas.ti. Pada tahap pertama, dilakukan open coding dengan memberi kode-kode yang sesuai dengan data yang terdapat pada transkrip.Kode-kode yang dihasilkan selanjutnya dikelompokkan ke dalam kategori. Setelah melakukan open coding, tahap selanjutnya adalah mencari hubungan antar kategori-kategori tersebut yang bertujuan untuk menghasilkan theoretical codes. Tahap terakhir proses analisis adalah dengan menetapkan kategori utama (main category) yaitu kategori yang berkaitan dengan sebanyak mungkin kategori yang telah dihasilkan sebelumnya (Utarini, 2000)..$^{10}$

Upaya pencapaian kredibilitas dilakukan melakukan triangulasi informan dan diskusi dengan sejawat.Peran pembimbing penelitian sebagai auditor menjaga derajat kebergantungan dan kepastian penelitian.

\section{HASIL PENELITIAN}

Keseluruhan narasumber yang terlibat dalam penelitian ini berjumlah 31 orang, terdiri dari 2 orang pimpinan, 7 orang dosen, 7 orang karyawan, dan 15 orang mahasiswa. Empat belas narasumber dengan jenis kelamin lakilaki dan 17 lainnya berjenis kelamin perempuan.Narasumber pada kegiatan FGD sejumlah 10 orang dan 21 orang dalam kegiatan wawancara.

Menurut narasumber, dosen telah memberikan materi yang up to date, menerapkan metode-metode belajar yang mengarah ke student centered learning (SCL), menjelaskan silabus pada awal perkuliahan, melakukan pengembangan mahasiswa, mampu menempatkan diri dan berperan dalam pencapaian visi misi institusi, serta sikap saling menghormati dan menghargai dalam membina hubungan dengan orang lain. 
akan tetapi, dosen dinilai kurang disiplin waktu dan jadwal perkuliahan serta ada beberapa yang dinilai diskriminatif.

".....kalau mahasiswa ada masalah dosen mau memberi pengarahan." (Narasumber 13N)

".....tapi ada beberapa dosen lebih mengutamakan anak yang lebih pintar atau anak itu anak yang lebih disukai." (Narasumber 12N)

"Yang saya keluhkan seringnya ada perubahan jadwal mendadak sehingga harus menjadwal ulang." (Narasumber 2N)

Karyawan sudah melaksanaan tugas sesuai dengan jobdescription, cukup bertanggung jawab, disiplin waktu, sikap saling berkolaborasi, saling membantu, dan bekerjasama.Akan tetapi, masih ada beberapa tugas yang tumpang tindih dan kurang komunikasi.

"Karyawan yang harus membersihkan perpustakaan yang sudah menjadi tanggung jawabnya tetapi selama ini dibersihkan ketika ada teguran dari atasan atau diminta petugas perpustakaan sehingga tanggung jawab terhadap amanat kurang." (Narasumber 1N)

Pimpinan telah berusaha memberikan bimbingan, dukungan, kepercayaan, dan penghargaan kepada staf.Pimpinan disiplin waktu dan tanggung jawab.Dalam mengambil keputusan sebagian besar diputuskan oleh pimpinan sendiri dan masih bersifat otoriter.

"Semacam rewardnya, tidak bentuk materi tapi bentuk penghargaan sikap, ucapan, saya kira itu." (Narasumber 17N)

Mahasiswa melakukan pengembangan diri, memiliki kepedulian terhadap orang lain, sikap saling menghormati.Akan tetapi, mahasiswa dinilai kurang disiplin waktu, melakukan plagiarism dan cheating, serta kurangnya kegiatan berorganisasi.

“............ada yang perlu dibenahi yaitu dalam hal ketepatan waktu. Misal jadwal jam 15.00 WIB tapi masih mengulur waktu, masuknya nanti saja." (Narasumber 1N)

\section{PEMBAHASAN}

Bimbingan dan pengarahan yang dilakukan oleh dosen bertujuan untuk memberikan kontribusi bagi pengembangan intelektual mahasiswa (Murray, 1996). ${ }^{6}$ Akan tetapi, dalam pelaksanaannya dosen dinilai masih diskriminatif terhadap mahasiswa, karena adanya kecenderungan yang mendapatkan bimbingan lebih banyak adalah anak-anak yang pintar. Hal ini tidak sesuai dengan UCLA (2013) yang menjelaskan bahwa perlakuan diskriminasi terhadap mahasiswa atas dasar politik, atau karena alasan ras, agama, jenis kelamin, orientasi seksual, etnis asal, asal negara, keturunan, status perkawinan, kondisi medis tidak boleh dilakukan ${ }^{11}$. Karena sikap diskriminasi tersebut akan mengurangi pengembangan mahasiswa (Murray, 1996). ${ }^{6}$ Sehingga diharapkan dosen menghindari tanda-tanda pilih kasih terhadap siswa dan memberikan perlakuan yang sama dan konsisten terhadap siswa (UCLA, 2013). ${ }^{11}$

Dosen dinilai kurang terutama terhadap disiplin waktu mengajar dan jadwal mengajar yang telah ditentukan oleh bagian akademik. Seperti yang dijelaskan UCLA (2013) bahwa salah satu perilaku dosen yang tidak dapat diterima adalah kegagalan untuk memenuhi tanggung jawab pengajaran, termasuk kegagalan yang signifikan untuk mematuhi aturan tanpa alasan yang sah dalam pelaksanaan program untuk memenuhi kelas, menjaga jam kantor, atau untuk mengadakan evaluasi sesuai jadwal. ${ }^{11}$ Kurang disiplin termasuk perilaku lack of conscientiousness, yaitu suatu kegagalan dalam memenuhi tanggung jawab dan tidak sesuai dengan esensi profesionalisme (University of Kansas School of Medicine, 2001). ${ }^{12}$ Kemungkinan hal tersebut disebabkan karena kurangnya kesadaran disiplin dosen, lingkungan yang kurang mendukung, dan kurangnya reward yang diterima. Hal ini senada dengan pernyataan Wijaya, A. E (2012), bahwa beberapa faktor yang mempengaruhi kedisiplinan dosen adalah kurangnya motivasi dosen, reward yang kecil, dan tidak adanya punishment. ${ }^{13}$

Tanggung jawab karyawan terhadap tugas yang diberikan dinilai masih kurang. Hal tersebut kemungkinan terjadi karena kurangnya reward yang diterima oleh karyawan. Menurut Gouzali Saydam (1996) sebagaimana disitasi oleh Damanik (2011), faktor-faktor yang mempengaruhi sikap tanggung jawab dan disiplin karyawan antara lain besar kecilnya pemberian kompensasi, ada tidaknya keteladanan pimpinan dalam perusahaan, ada tidaknya aturan pasti yang dapat dijadikan pegangan, keberanian pimpinan dalam mengambil tindakan, ada tidaknya pengawasan pimpinan, ada tidaknya perhatian kepada karyawan, dan diciptakan kebiasaan-kebiasaan yang mendukung tegaknya tanggung jawab dan disiplin. ${ }^{14}$ 
Mary Keen sebagaimana disitasi oleh Berliana (2013) juga memberikan sebuah checklist di mana karyawan dapat menilai sejauh mana perilaku mereka sebagai seorang karyawan, antara lain apakah karyawan dapat diandalkan yaitu tepat waktu setiap hari, jika sakit atau tidak dapat bekerja maka segera memberitahu atasan, dan berbicara secara positif kepada karyawan yang lain. Selain itu, apakah karyawan cukup fleksibel, yaitu memiliki sikap memberikan yang terbaik atas tugas yang diberikan pada hari itu dan selalu siap untuk mendapatkan tanggung jawab yang baru. ${ }^{15}$

Pimpinan telah memberikan penghargaan kepada bawahan terhadap keputusan yang diambil dan memberikan penghargaan terhadap hasil kerja bawahannya. Menurut Syafrizal (2013), yang termasuk ciri-ciri seorang pimpinan yang profesional antara lain memberikan penghargaan pada setiap karyawan yang berprestasi (kompensasi termasuk peluang pendidikan, pelatihan lanjutan dan promosi karir), dan persuasi pada karyawan yang kurang berprestasi untuk menjadi yang terbaik melalui konsultasi dan bimbingan serta pendidikan dan pelatihan secara berkesinambungan. ${ }^{16}$

Salah satu ciri seorang pemimpin menurut Gerry R Terry sebagaimana disitasi oleh Hasyim (2013) adalah memiliki human relationship, yaitu mempunyai pengetahuan tentang hubungan manusia. ${ }^{17}$ Hubungan yang baik antara pimpinan dan bawahan akan menciptakan iklim kerja yang kondusif. Seperti pendapat Dharma (1984) sebagaimana disitasi oleh USU (2011), pemimpin dituntut untuk membina hubungan baik dan menyenangkan dengan bawahan dalam usaha mencapai tujuan organisasi. ${ }^{18}$ Penelitian yang dilakukan oleh Situmorang (2006) mengemukakan, bahwa semangat kerja karyawan dipengaruhi secara positif oleh kondisi kerja, hubungan atasan bawahan dan atau sesama pegawai, organisasi tempat bekerja, dan pemenuhan kebutuhan pegawai. ${ }^{19}$

Mahasiswa dinilai kurang disiplin terhadap waktu dan peraturan yang berlaku di institusi.Hal ini senada dengan penelitian yang dilakukan oleh Ainsworth, M. A and Szauter, K. M (2006), bahwa mayoritas responden menyatakan penyimpangan perilaku profesional mahasiswa terkait tanggung jawab dan integritas. ${ }^{20}$ Menurut MSU (2008), seharusnya mahasiswa menyadari bahwa sebagai seorang profesional dia memiliki tanggung jawab untuk memastikan bahwa tujuan profesional terpenuhi pada kondisi apapun. Seorang mahasiswa yang menerima tanggung jawab profesional akan memberikan kontribusi dalam pembelajaran yang positif dan lingkungan disekitarnya. Mahasiswa akan hadir dan tepat waktu untuk kegiatan yang merupakan bagian integral dari pengalaman dan kebutuhan belajarnya. Mereka akan bertanggung jawab untuk memberitahu orang lain terlebih dahulu bila memungkinkan ketika terlambat. ${ }^{21}$

Kurangnya disiplin mahasiswa dapat disebabkan oleh beberapa hal, antara lain kurangnya kesadaran mahasiswa, kebiasaan, ataupun pengaruh dari lingkungan. Hal ini sesuai dengan pendapat Slameto (2003), yang menyatakan bahwa faktor yang mempengaruhi disiplin siswa yaitu adanya dorongan dari dalam diri siswa (intern) seperti pengetahuan, kesadaran, ketaatan, dan latihan berdisiplin. Sedangkan dorongan dari luar siswa (ekstern) mencakup lingkungan, teman, saudara, kebiasaan pembinaan dari rumah, pengawasan, hukuman, nasehat dan sebagainya. $^{22}$

\section{KESIMPULAN DAN SARAN}

Sebagian besar narasumber menilai bahwa perilaku profesional institusi cukup baik. Akan tetapi masih ada hal-hal yang perlu diperbaiki dan ditingkatkan.Saran perbaikan yang diajukan meliputi penambahan jumlah staf dosen, peningkatan kualitas SDM, peningkatan kesejahteraan karyawan, pengadaan manual prosedur atau SOP, dan penambahan fasilitas kampus.

Keseluruhan saran tersebut sangat mempengaruhi perilaku profesional institusi baik dosen, karyawan, pimpinan maupun mahasiswa.Sehingga institusi perlu memperhatikan saran yang telah disampaikan ini dan selanjutnya untuk memikirkan langkah perbaikan selanjutnya demi meningkatkan perilaku profesional institusi.

\section{DAFTAR PUSTAKA}

1. Frenk, J. et. al. (2010). Health professionals for a new century: transforming education to strengthen health systems in an interdependent world. Lancet; 376: 1923-58.

2. Hafferty, F. W \& Castellani, B. (2009). A sociological framing of medicine's modernday professionalism movement. Medical Education; 43: 826-828. Blackwell Publishing Ltd.

3. Passi, V et. al. (2010). Developing medical professionalism in future doctors: a 
systematic review. Diunduh dari http://creativecommons.org/licenses/by/3.0 tanggal 21 November 2012.

4. Green, H. (2004). Professional Standards for Teachers and School Leaders. New York : RoutledgeFalmer.

5. AAMC and NBME. (2002). Embedding Professionalism in Medical Education: Assessment as a Tool for Implementation. Baltimore - Maryland.

6. Murray, H., et. al. (1996). Ethical Principles in University Teaching. Society for Teaching and Learning in Higher Education. Centre for Teaching and Academic Growth: Vancouver BC.

7. Satori, D dan Komariah, A. (2010). Metodologi Penelitian Kualitatif. Bandung : Alfabeta.

8. Riduwan. (2004). Metode dan Teknik Menyusun Tesis. Bandung: Alfabeta.

9. Mc.Millan, J.H and Schumacher. (2001). Research In Education a conceptual introduction. New York \& London: Longman.

10. Utarini, A. (2000). Metode Penelitian Kualitatif, Magister Kesehatan lbu dan Anak. Yogyakarta: Inpress.

11. UCLA. (2013). Professional Behavior. Office of Instructional Development, 70 Powell Library. Los Angeles.

12. The University of Kansas School of Medicine. (2001). Professionalism Initiative. Kansas.

13. Wijaya, A. E. (2012). Beda Nasib Disiplin Dosen UII. Kobar-Kobari Edisi 156 / Tahun Ke-14 / April 2012.
14. Damanik. (2011). Integritas dan Disiplin SDM. Diunduh dari meylinadamanik.blogspot.com/2011/07/integritasdan-disiplin-sdm.html?m=1 tanggal 5 Juni 2013.

15. Berliana, R. (2013). Menjadi Karyawan Teladan Sebagai Suatu Sikap Profesional. Diunduh dari vibizmanagement.com/column/index/categ ory/human-resources/2371/10. tanggal 23 April 2013.

16. Syafrizal, M. (2013). Manajemen Profesional. Diunduh dari www.academia.edu tanggal 23 April 2013.

17. Hasyim. (2013). Ciri-ciri Manajer SDM yang Profesional. Pusat Pengembangan Bahan Ajar Universitas Mercu Buana.

18. Universitas Sumatera Utara. (2011). Pengaruh Sifat Kepemimpinan terhadap Motivasi Kerja Karyawan PT. Gold Coin Indonesia. Medan

19. Situmorang. (2006). Faktor-faktor yang Mempengaruhi Semangat dan Gairah Kerja Pegawai di Lingkungan Kantor Pelayanan Pajak (KPP) Metro. Lampung.

20. Ainsworth, M. A. and Szauter, K. M. (2006). Medical Student Professionalism: Are WeMeasuring the Right Behaviors? AComparison of Professional Lapses by Students and Physician. Acad Med. 2006;81(10 Suppl):S83-S86.

21. MSU. (2008). Professional Behavior Expectations. CHM Office of Admissions.

22. Slameto. (2003). Belajar dan Faktor-faktor yang Mempengaruhinya. Jakarta : Rineka Cipta 